\title{
A Path Transition Towards a Bioeconomy-The Crucial Role of Sustainability
}

\author{
Erik Gawel $^{1,2, * \mathbb{D}}$, Nadine Pannicke ${ }^{1}$ and Nina Hagemann ${ }^{1}$
}

1 Department of Economics, Helmholtz Centre for Environmental Research-UFZ, Permoserstraße 15, 04318 Leipzig, Germany; nadine.pannicke@ufz.de (N.P.); nina.hagemann@ufz.de (N.H.)

2 Institute for Infrastructure and Resources Management, Leipzig University, Grimmaische Str. 12, 04109 Leipzig, Germany

* Correspondence: erik.gawel@ufz.de; Tel.: +49-341-235-1940

Received: 30 March 2019; Accepted: 22 May 2019; Published: 28 May 2019

\begin{abstract}
The bioeconomy is a worldwide used strategy to cope with ecological, social, and economic sustainability challenges. However, we analyze current bioeconomy strategies and trends to point out potential sustainability conflicts and transition challenges. Our analysis shows that the bioeconomy is not sustainable per se, as mere input substitution may entail welfare losses. Instead, it requires further debates and actions to avoid exacerbation of ecological and social strains. Sustainability has to be the key concept behind the bioeconomy and predominantly requires (1) sustainability of the resource base and (2) sustainability of processes and products, especially by (3) circular processes of material fluxes, not least to gain consumer acceptance for bio-based products. Otherwise, the bioeconomy would only entail the substitution of fossil resources for bio-based resources potentially lacking the generation of additional societal and ecological benefits and contribution to climate mitigation. As markets alone will not suffice to fulfil this path transition towards a sustainable bioeconomy, we argue that innovative governance is necessary to reduce competitive drawbacks compared to fossil resources (enabling function) and to secure ecological, social, and economic sustainability requirements (limiting function).
\end{abstract}

Keywords: bioeconomy; transition; governance; integrated policies; sustainable development goals (SDGs); sustainability conflicts

\section{Introduction}

The global economy has to feed an increasing world population with a simultaneous rise of the living standard, but is restricted by planetary boundaries [1]. Here, the concept of using bio-based resources ("bioeconomy") might be a promising contribution to a transformation towards a sustainable economy and way of living [2-5]. The sustainability of current production and consumption patterns may be improved through a change from a fossil-based throughput economy towards a bioeconomy with bio-based and recirculated products and renewable energy [5]. Thus, an important contribution to the compatibility of societal development with long-term protection of our livelihoods may be accomplished.

The bioeconomy is associated with far-reaching expectations regarding a number of sustainabilityrelated policy aims, such as climate change mitigation, energy security, technological progress, environmental protection, employment, growth, and rural value creation. Over the last decade, the bioeconomy has received increasing political attention, with many countries and international bodies (such as the OECD and EU) adopting strategies to express their support of the concept (e.g., [2,6]; for overviews, see [7-11]. The European Commission defines the bioeconomy as the knowledge-based "production of renewable biological resources and the conversion of these resources and waste 
streams into value added products, such as food, feed, bio-based products and bioenergy" [2] (p. 3). This political interest is also reflected in research funding agendas such as the EU's Horizon 2020 Framework Programme for Research and Innovation, where the bioeconomy features prominently as part of one of six key societal challenges [12]. The German Federal Ministry of Education and Research has likewise released a "National Research Strategy BioEconomy 2030" [13], which was updated for the period post $2017[14,15]$.

So far, the essence of the definitions of the term "bioeconomy" seems to be the resource base, i.e., economic activity based on renewable bio-based resources (cf. Reference [16]), but not the sustainability of the economy and way of living (cf. References [17-19], for details see Section 2). However, sustainability is not per se attainable by using renewable resources as could be learned from the case of sustainability issues regarding bioenergy use (cf. e.g., References [20-24]). Thus, sustainable bioeconomy requires three prerequisites:

1. Sustainability of the resource base (e.g., bioenergy: real GHG-savings),

2. Sustainability of both production and consumption processes and products (in particular environmental compatibility), and

3. Circular processes of material fluxes.

The development of bioenergy support policy, as part of a bioeconomy-oriented policy, has clearly shown the sustainability challenges that accompany the introduction of an additional, politically driven demand for biomass and land resources. Just as with the bioeconomy concept, bioenergy has been associated with high expectations regarding various policy aims-primarily greenhouse gas (GHG) mitigation, security of energy supply, and rural development (e.g., References [25,26]). However, conflicts within this triangle of aims and also with further societal aims soon became obvious, and sparked a broad societal and scientific debate about the sustainability risks involved (see References [27-29] for overviews).

While in the bioenergy context a controversial sustainability debate was hold, a debate on the bioeconomy as a whole is still pending. Up to now, the media attention for bioeconomy issues is very limited [30]. Furthermore, numerous, even new trade-offs due to the bio-based economy appear, that have to be tackled in the context of sustainability strategies. Moreover, new types of technologies with standard technology assessments are necessary. All in all, great lengths have to be gone to overcome uncertainties regarding the sustainability of the bioeconomy.

Consequently, the concept of bioeconomy is also subject to strong criticism because of the insufficient availability and potentially unsustainable use of biomass and land, which are the primary constraints for the further development of the bioeconomy sector [31-33]. The politically intended rise of the demand for bio-based products will further increase the pressure on limited biomass and land resources and intensifies the interactions with the food sector [34-37]. Conflicts between different sustainability targets such as food security and energy supply, sustainable land use, and land use conflicts apart from biomass production such as nature protection and tourism may exacerbate and induce ecological, economic, social, and political consequences (for an overview see, e.g., References [21,28,29,38].

The multifaceted critique of an "industrial utilisation of nature" due to bio-based inputs in various production processes (cf. References [39-42]) is not surprising. Interestingly, an alleged sustainability project is subject to intense sustainability critique. Hence, what is the role of sustainability for the bioeconomy? For this purpose, many papers were published recently. Most of them criticise the technological focus while disregarding the environmental and socioeconomic effects and excluding society (cf. e.g., References [18,19,43-47]).

In this paper, we conducted a qualitative literature study from an environmental economics perspective to grasp and discuss the most decisive ecological, economic, and social sustainability risks for the bioeconomy. We focus on the wood-based bioeconomy as an example to enhance clarity and comprehensibility and because it is seen as ecologically (e.g., less fertilizers and effort needed for 
biomass production) and socially advantageous (e.g., less competition to food production) over the crop-based bioeconomy. Moreover, we rely on our own specific research evidence on the wood-based bioeconomy, apart from this we assume general findings for the bioeconomy.

To begin with, we clarify our understanding of sustainability and present insights in how the bioeconomy is currently defined, framed and conceptualized in political strategies and scientific articles (Section 2). Based on this, the paper analyses critically the resulting sustainability challenges of the bioeconomy in Section 3, focusing on the wood-based bioeconomy as an example. This provides the knowledge base for the transition challenges towards a sustainable bioeconomy discussed in Section 4 . As a result, the paper derives some key messages for policy makers, entrepreneurs, and interested society on the challenges and required steps to ensure a sustainable path transition (Section 5).

\section{Defining, Framing and Conceptualizing the Bioeconomy}

As a start, our understanding of sustainability is based on the most prominent three pillar model, where the three pillars represent the environment, economic and social dimensions and sustainable development is seen as achieved when all the pillars are considered equitably [48]. Despite several points of critique [49] and for reasons of straightforwardness and tangibility, we focus on the three pillar model in this paper and do not take the numerous suggested approaches and models for sustainability and sustainable development into further consideration (for an overview in the bioeconomy context, please see Reference [45]).

In the 1980s, the term "bioeconomy" was used to describe a sustainable economy based on the energy of the sun, which fits in ecological boundaries without the permanent compulsion to grow (cf. $[40,50])$. In the 1990s, the bioeconomy was redefined as a "business sector that utilizes new biological knowledge for commercial and industrial purposes" ([50] (p. 27), see also References [51,52]). Picking up that impulse, in combination with the parallel development of a Strategy on Biotechnology in 2002, this was the foundation for the "Knowledge-based Bioeconomy" (KBBE) in 2005 [53]. That is why the biotechnology plays a key role for the emergence of the bioeconomy and seems to be an inherent part of its past and further development. The European Commission (EC)'s DG Research organised a conference on the KBBE in 2005, which emphasised the role of life sciences and biotechnology in transforming natural and biological resource-based sectors [54]. In the conference report, the knowledge-based bio-economy was defined as "a sustainable economy based on renewable resources" [54] (p. 3), which would not only contribute to "finding more environmentally friendly production methods and pushing forward the frontiers of science" [52] (p. 1), but also to secure resource supply in times of diminishing oil supplies [54] (p. 3). Moreover, it was expected that Europe's competitiveness would increase with new bio-based goods and services [54] (p. 3).

Meanwhile, several definitions of the term "bioeconomy" exist and a consistent understanding of the concept is still lacking. Comparing a set of national and international bioeconomy strategies (including those by the German Federal Ministry of Food and Agriculture [55], the OECD [6] and the EU [2]), De Besi and McCormick find a common focus on "fostering research and innovation, primarily in the field of biotechnology; promoting collaboration between industry, enterprises, and research institutions; prioritising the optimized use of biomass by implementation of the cascade principle and by utilising waste residue streams; and providing funding support for the development of bio-based activities" [7] (p. 10473). However, the bioeconomy can still be seen as a "chameleon of notions" [50] that adapts repeatedly to changing requirements [52]; the meaning of the bioeconomy "still seems in a flux" [56], maybe as a consequence of its role as a "master narrative" attracting rival visions [57].

The OECD defines three elements relevant for a bioeconomy: "biotechnological knowledge, renewable biomass, and integration across applications" [6] (p. 22). At the same time OECD admits that "sustainable development depends on economic growth that maintains environmental sustainability [... ] [what] requires decoupling economic growth from environmental degradation" [6] (p. 22), but keeping economic sustainability as the main goal. 
In the EU-Cologne-Paper "En Route to the Knowledge-Based Bio-Economy", it is requested that life sciences knowledge should be used to create products that are sustainable, eco-efficient and competitive, showing an early focus on economic aspects such as innovation and competitiveness in the EU [58]. The later strategies and definitions on bioeconomy contain few aspects of sustainability, e.g., in their title "Innovating for Sustainable Growth", but keeping emphasis on economic growth [2]. Ramcilovic-Suominen and Pülzl conclude that the bioeconomy debate in the European Union is not balanced in terms of sustainability because the economic dimension prevails over environmental and social aspects of the bioeconomy [45]. As well, a comprehensive embedding of the bioeconomy concept into "sustainable development" and the goals relating thereto are missing.

Similarly, the German Bioeconomy Council mentions that sustainability has a role in the bioeconomy (the "structural change towards a sustainable bio-based economy") [58]), but it is not fleshed out. Growth and employment remain the key priorities. In the definition of the German Federal Ministry of Food and Agriculture sustainability is not an inherent part of the bioeconomy, but it is acknowledged that the bioeconomy is oriented on natural material cycles and the bioeconomy strategy calls for sustainable resource use [55].

The German "National Research Strategy BioEconomy 2030" emphasises the vision of a "natural cycle-oriented, sustainable bio-based economy" [13] (p. 3), whereas the German "National Policy Strategy on Bioeconomy" is explicitly linked to the Federal Government's Sustainability Strategy [55] (p. 8). Nonetheless, sustainability is not perceived as the focus of political endeavours-rather, the dominance of an industrial perspective is frequently criticised (e.g., References [22-24,40,45,59].

Inversely, the new Sustainability Strategy of the German Federal Government [60] links the bioeconomy to the Sustainable Development Goals (SDGs). Thus, the bioeconomy does not only contribute to a sustainable economic growth and full employment (SDG 8) as well as infrastructure development, industrialisation, and innovation (SDG 9), but also to sustainable production and consumption patterns (SDG 12) and to the protection, recreation, and sustainable management of terrestrial ecosystems (SDG 15) [61]. Frequent references to the German "National Policy Strategy on Bioeconomy" [55] and the German "National Research Strategy Bioeconomy 2030" [13] give the impression that sustainability and the path to a sustainable development are well defined and deep-seated in these strategies, but this is by far not the case. Instead the strategies give backlinks to each other, but do not define specific actions for a real transition towards sustainability. Furthermore, the content-related arrangement of the German Sustainability Strategy reflects the prioritisation of the three pillars of sustainability in the German bioeconomy strategies: the economic pillar seems to be far more important than ecological and social sustainability issues.

Moreover, the European Commission is aware of the crucial role of policies, especially for science, technology and innovation to foster sustainable development [62]. However, to make the bioeconomy a vehicle for sustainability transition requires more, in particular policies on the sustainability of resources and socioeconomic aspects (further specified later on).

Even though sustainability is mentioned in all of the prominent definitions and strategies for the bioeconomy by now, it is of minor importance or utilized as an empty or arbitrary phrase and not fleshed out. Ramcilovic-Suominen and Pülzl [45] find that the European bioeconomy policy has an "industrial perspective" that neglects especially the role of farmers and they criticize that, for example, the EUs "Innovating for Sustainable Growth: a Bioeconomy for Europe" [2] lost the focus on sustainable resource management and instead focuses on improving the productivity of biomass production. The latter understanding tends to be accompanied by an industrial policy-centred vision, which emphasises the bioeconomy's contribution to an innovative, competitive, and growing economy, but fails to comprehensively address concerns about the sustainability of developments. Moreover, in the EU, mandatory sustainability criteria mainly refer to land protection (e.g., usage restrictions due to nature conservation laws) and GHG-savings, but ignore socioeconomic aspects as part of a comprehensive sustainability approach, e.g., social issues would arise as, for example, in terms of land and respective land rights [46] or in the production process [63]. 
In the international scientific and public debate, different categories and descriptions of the bioeconomy can be pigeonholed in two general alternative interpretations of the bioeconomy: A normative vision, where the bioeconomy is part of a broader path transition from a fossil-based "throughput economy" towards a sustainable circular flow economy based on renewable resources; and a positive understanding of the bioeconomy as an umbrella term for bio-based sectors of the economy, i.e., production of bio-based materials, in particular agriculture and forestry, as well as processing of bio-based raw materials, e.g., food industry, wood-processing industry, textile, chemical, and pharmaceutical industry or parts of energy industry or environmental industry [13], mainly characterized by a resource substitution and a biotechnology innovation perspective [52].

Bugge et al. [44] distinguish between a (i) bio-technology vision (focus on research, application and commercialisation of bio-technology), (ii) bio-resource vision (focus on processing and upgrading of biological raw materials and establishment of new value chains) and (iii) bio-ecology vision (focus on sustainability and ecological processes for environmental improvements). While the bio-ecology vision mainly reflects the normative vision of the bioeconomy, the bio-resource and bio-technology visions represent the positive vision and differentiate between production and processing of raw materials.

Birch [64] differentiates between four definitions of the bioeconomy: (i) Product definition (bio-based products), (ii) substitution definition (substitution of fossil resources for bio-based ones), (iii) renewable-sustainable definition (critical debate whether renewable = sustainable) and (iv) societal transition definition. The product definition fits into the positive understanding of the bioeconomy, while the substitution definition, the renewable-sustainable definition, and the societal transition definition lean towards the normative understanding of the bioeconomy, representing different aspects of this vision.

Ramcilovik-Suominen and Pülzl [45] distinguish four different narratives in the EU bioeconomy framework: (1) Primary production narrative, (2) efficiency narrative, (3) competitiveness narrative, and (4) sectoral capacity narrative. Here, all the four narratives comply with the positive understanding of the bioeconomy, while the normative vision of the bioeconomy as part of a broader path transition towards sustainability receives no consideration.

For a holistic understanding and to avoid negligence of potentials for the bioeconomy, all objectives, interests and challenges of the different perspectives on the bioeconomy should be considered [65]. Apart from different interpretations and visions of the bioeconomy, specific concerns regarding bioeconomy strategies (e.g., German bioeconomy policy and research strategies and those of the German federal states) point to several problems, such as (i) an insufficient consideration of conflicts between environmental and economic policy aims; (ii) open questions on how to effectively safeguard environmental boundaries and global food security; (iii) a lack of a broader transformation perspective; and (iv) insufficient participation of civil society in strategy development and bioeconomy governance $[18,22,43]$.

Regarding the criticism on the bioeconomy concept, two major types can be distinguished: The "fundamental critique" and the "greenwashing critique" [52]. Meanwhile, there are also extreme forms of fundamental critique, warning that the bioeconomy pursues "the unlimited commercial use of all life" [39] (p. 7), own translation) for the "neoliberalization of nature" [41], which secures a "regime of accumulation against major sociopolitical and ecological challenges" [42].

As the first consequence, the bioeconomy concept has been embedded more explicitly to sustainable development and its focus was shifted from the supply side (technology innovation) to the demand side (consumer and society) in recent years [52]. According to Grefe [50], a significant change has emerged: While in the beginning, the focus of bioeconomy strategies was mainly on the use of biological knowledge due to the application of biotechnology, sustainability, the support of regions and a role of the bioeconomy as the green part of a circular economy have been brought to the fore. Some authors state promising potentials for the bioeconomy to make a significant contribution to the SDG's $[5,66]$ and consider the bioeconomy as a valid and reliable way to the transition to equitable, sustainable, post fossil-carbon societies $[67,68]$. As the SDG's cover nature, economy and society as 
the three pillars of sustainability, the question remains, how and in what way the bioeconomy can support synergies of diverse sustainability goals from different pillars and thus, help to contribute to as many SDGs as possible. Previous research outlined 11 out of 17 SDGs to be potentially highly relevant to a developing global bioeconomy [66,69], but as the SDGs represent complex and interlinked socioeconomic relationships of sustainability as a holistic subject, they cannot be put into a hierarchical order [70]. To meet challenges due to normative conflicts resulting from the complexity of the bioeconomy, stakeholder participation is the most appropriate means to identify societal interests and perceptions and to identify key objectives, for instance, the goals "Zero Hunger" (SDG 2), "Responsible Consumption and Production" (SDG 12), "Life on Land" (SDG 15), "Life below Water" (SDG 14) and "Clean Water and Sanitation" (SDG 6) have been categorised as the most important ones for monitoring the bioeconomy by stakeholders from science, business, and society in Germany [70].

So far, although the bioeconomy concept has been linked to sustainable development and shifted from a technology- to a more society-centred focus as a response to the criticism in recent years, the doubts remain, if sustainability aspects are addressed satisfactorily in political strategies and policymaking for a transition towards a sustainable bioeconomy development. In the first place, sustainability conflicts (Section 3) and transition challenges (Section 4) need to be carefully thought out.

\section{Sustainability Conflicts of the Wood-Based Bioeconomy}

Some definitions suggest that the bioeconomy is not per se sustainable just because it is based on renewable resources and it is not per se able to solve sustainability problems; sometimes it even brings about new challenges [21,71], such as "peak soil" and "peak water" [19]. Potentially, not only the cultivation of biomass but also uncertain effects of technologies such as costs, quality, life cycle balances, and impacts of bio-based processes can give rise to sustainability risks. Therefore, in this section we will first outline the implications of our understanding of sustainability for the bioeconomy in general and its, as seen in Section 2, historically rooted inherent elements bioenergy and biotechnology. In this context, we will discuss the role of innovations in the bioeconomy and take the wood-based bioeconomy as an example. In the end of this section, we argue the most decisive sustainability advantages and subsequently juxtapose the sustainability risks of the bioeconomy to set up a starting point for the discussion of transition challenges and the role of governments in the following Section 4 .

Hitherto, the strategies analysed in Section 2 highlight that the bioeconomy needs to contribute to a more sustainable use of natural resources (e.g., References $[2,6,55,61])$, but detailed ideas about ecological and social sustainability aspects are missing in all the above mentioned documents, let alone a systemic view on complex socio-ecological systems [18]. Neither a connection to self-imposed goals of the global community, e.g., the Convention on International Trade in Endangered Species of Wild Fauna and Flora or climate protection goals, are evident, nor the perspective of a profound transformation that goes beyond maintaining the status quo. A sustainable bioeconomy necessitates the strengthening of the social and ecological view that is so far not sufficiently addressed in the strategies. A sustainable bioeconomy is only feasible if, and only if, all three pillars of sustainability are taken into account from the very beginning and if synergies between these pillars can be achieved. In doing so, usually none of these three pillars is maximized, but instead the optimal combination of these pillars is prospected and implemented.

The main constraints for the further development of the bioeconomy sector are impending scarcities of sustainably grown feedstocks for bio-based products due to the insufficient availability and inefficient use of biomass and arable land [31,33]. This may cause rising prices for biomass and land on the one hand and consumer concerns about the sustainability of resource inputs for the bioeconomy on the other hand. This may challenge ecological viability, economic feasibility and social acceptance at the same time. Into the bargain, the planned rise of the demand for bio-based products will further increase the pressure on limited biomass and land resources. That intensifies the interactions with the food sector and therefore conflicts between different sustainability targets such as security of food and 
energy supply, sustainable land use, and land use conflicts apart from biomass production such as nature protection and tourism are likely to increase.

As already seen in the context of bioenergy, an increased demand for biomass and land caused several sustainability conflicts. Special attention has been called to the direct and indirect land use change effects of an increased biomass demand, which negatively impact the GHG and wider environmental balances of crop-based bioenergy pathways in particular (because of incentives for agricultural intensification and expansion of agricultural areas). Social sustainability concerns were expressed e.g., in the food vs. fuel debate and discussions about land grabbing for biomass production. But also the economic sustainability of bioenergy pathways was called into question, particularly with regard to the persistently high GHG mitigation costs of biofuels (e.g., References [72,73]). This critique eventually led to adjustments of policies, such as the introduction of a cap on the contribution of food crop-based biofuels to the Renewable Energy Directive's 2020 target for the share of RES in the transport sector [74]. Despite improvements, future bioenergy policies should support a more efficient, demand-oriented bioenergy, which is integrated step-by-step in a comprehensive renewable energy system (cf. Reference [75]). Moreover, there is ongoing uncertainty about the future development of bioenergy policies.

With an industrial policy-centred vision of the bioeconomy, it is all too easy to imagine a repetition of the problems of the bioenergy policy, albeit potentially on a larger scale given the number of economic sectors involved. This emphasises the importance of establishing sustainability at the core of bioeconomy policy development, including credible strategies for addressing conflicts between aims and implementing effective sustainability safeguards. Thus far, the potential negative impacts of the biomass use on a massive scale shall be reduced by means of novel technologies.

For instance, the German Bioeconomy Council still promotes biotechnology as a magic bullet for solving all sustainability problems regarding scarce biomass resources (see e.g., Reference [76].) Albeit, there is a step forward in bioeconomy strategies to contribute to the SDGs and the Paris Agreement [70], for instance, ecological boundaries of a bioeconomy are proposed to be respected, circular economy approaches are taken into account [77] and a resource, nature and climate friendly and an ethically acceptable production ought to be the valuation standard for the bioeconomy [15]. However, bioeconomy policies in Germany, the EU and the OECD-countries still focus on the time-honoured understanding of the "knowledge-based bioeconomy" which is predominantly characterized by the substitution of resource inputs and high tech innovations, mainly in the form of biotechnology (e.g., References [2,15]).

Indeed, this is a short-term view, as this may create new sustainability conflicts (for an overview see, e.g., Reference [78]): The "sustainability joker" biotechnology as a high-tech sector may raise huge sustainability risks, especially when upscaling biotechnological processes to an industrial scale as these may absorb any natural resources indifferentiatedly, just like a vacuum cleaner (cf. References $[22,32,39,40]$ ). As large-scale biorefineries have a relatively constant and high biomass demand, spatial and temporal high and variable biomass streams can proof problematic and quite likely demand large-scale exports and imports, which may be challenging for social acceptance. Furthermore, uncertainties regarding enticing innovative biotechnological solutions as alleged only means are commonly neglected [42].

In this spirit, the series of positive expectations regarding the bioeconomy, such as a contribution to climate and resource protection, should be realized by means of economic growth and innovation [15,77]. Certainly, this is a first contradiction in itself concerning economic vs. ecological sustainability, if decoupling of economic growth from environmental degradation won't be pursued. In this sense, innovations are both, part of the problem, but also part of the solution to the sustainability problem [79]. Concepts for responsible or social innovations can provide future-oriented remedies (see Section 4). Even if we leave the "sustainability or collapse" narrative [80] behind, environmental changes resulting from human activities will, sooner or later, require transformation and/or reorganisation of economic habits and lifestyles (cf. [81]). 
Current endeavours in bioeconomy still boil down to innovative products, whether in terms of production processes or in product characteristics and performance, at best both in combination. But successful innovations are only feasible, if improvements are noticeable or an existing gap is filled [82]. In fact, bio-based products are often substitutes of existing products, keeping the properties, but only differing in the resource base. Regarding such Drop-In products, the only noticeable improvement for the consumer is a step towards sustainable production, realized in this case by the substitution of the resource base from fossil- to bio-based. However, as the bioeconomy is in the ungrateful role as a straggler of bioenergy, it has got the problem that sustainability, in particular a sustainable renewable resource base, is doubted in public perception [17] so that it is hard to gain credibility and acceptance for a sustainability improvement by means of the bioeconomy. Since the Prefix "Bio" has lost its innocence (cf. [50,83]), the environmental benefits of bio-based products are even more critical attributes of trust in need of explanations [84,85]. Even in the public debate on bioeconomy the substitution of the resource base is the main issue [86]. Mainly for this reason, there is a controversial discussion on the bioeconomy, as for example a media analyses from Finland [43] revealed. In a nutshell, as features of bio-based products are similar to fossil-based ones [87], but are offered for higher prices [88,89] and may cause sustainability concerns (cf. Reference [21]), consumer acceptance of bio-based products struggles with several challenges (for an overview see Reference [90]), but after all, sustainability is the key for purchasing decisions in favour of the bioeconomy.

Moreover, a sustainable development of the bioeconomy requires innovative technical and, above all, political solutions for stimulating a change of consumption patterns and the use of waste and recycling material, taking into account possible rebound effects [91,92]. The discourse about a sustainable bioeconomy needs to be linked with expanding the circular flow economy, to reduce pressures on ecosystems that provide primary biomass resources [93]. However, to improve resource efficiency and close material cycles, novel technological, organisational and product solutions are required $[19,61,88,94]$, e.g., integrated lignocellulosic biorefinery concepts. But also material-focused climate policies which reward the use of less resource-and energy-intensive materials such as wood-based materials are one possibility to achieve climate protection goals, for instance by supporting a wood-based bioeconomy [95], e.g., by fostering wood-based buildings.

In the course of urbanisation, "business as usual" infrastructure development in cities and urban districts challenges climate protection goals and sustainable development goals (SDGs). As cement, steel and aluminium require huge amounts of energy and resources to be produced and transported, and cause sizable GHG-emissions, climate-friendly construction materials are needed [96]. If infrastructure development in emerging economies and developing countries would be based on cement, steel, and aluminium as it was and is in industrialized countries, then this could cause an estimated $350 \mathrm{Gt}$ of $\mathrm{CO}_{2}$-emissions until 2050 [97]. This amount of GHG-emissions is equivalent to roughly one third of the whole available $\mathrm{CO}_{2}$-budget if climate change is to be limited to less than $2{ }^{\circ} \mathrm{C}$, and it is equivalent to more than three quarters of the available $\mathrm{CO}_{2}$-budget if climate change is to be limited to $1.5^{\circ} \mathrm{C}$ [96]. Instead, wood and wood-based materials can serve as examples for climate-compatible construction materials demanding less energy and resources for production and transport, emitting less GHG and serving as carbon sinks $[55,98,99]$. Due to these advantages, wood buildings are constituted as no-regret-option for climate protection $[100,101]$.

While the share of wood as a building material in new single family houses and non-residential constructions is already high ( $46.9 \%$ and $51.2 \%$, respectively) (cf. Reference [102]), the use of wood in multi-storey residential buildings is also increasing. In Berlin, the first seven-storey wooden construction building in a European metropolitan central district was completed in 2008 [103] and the Stadthaus at Murray Grove in London as a 9-storey apartment block was completed in 2009 [104]. Among others, a 24-storey wooden tower will be built in Vienna and a 34-storey skyscraper is planned to be built in Stockholm [105]. Additionally, for renovation and heightening of existing buildings in cities wood use opens up new opportunities for the creation of urgently needed housing space in cities [101,105]. 
The "wood economy" has a long tradition, whereas the fossil age just began. While the conventional use of wood is experiencing a renaissance, a wide range of innovative applications, i.e. novel and progressive solutions mainly due to new products or processes, especially materials made of e.g., cellulose, hemicellulose and lignin, are emerging [106]. Selected examples, among others, for innovative or reinvented products and applications are cross-laminated timber products in wooden multi story buildings $[107,108]$, shaped wood in cars [109,110], admixture in concrete [111,112], biocomposites such as wood-plastic composites (WPC) or natural fibre reinforced composites $[113,114]$ or Nanocellulose (NC) [115]. In the future, lignin could also be employed to produce for example fine chemicals, bioplastics [106] or glues [116,117]. Furthermore, the wood-based bioenergy plays an important role in subsistence economies, but also for the transition to renewable-based energy systems in the developed world (cf. [118]). Especially in private forests and rural areas wood is the basis for self-provision of energy and survived during the fossil age in the developed world. Generally, the wood-based bioeconomy as part of the overall bioeconomy can contribute to a more sustainable economy, if sustainability issues are addressed and sustainability-oriented innovations are stimulated. However, while conventional material and also energy wood uses are comparatively well established, consumer demand for innovative material wood-based products remains low.

The wood-based bioeconomy was focussed when the crop-based bioeconomy concept triggered a food versus fuel discussion, as this was thought to have no competing uses with basic needs. The analysis of bioeconomy strategies around the world shows that especially forest rich countries such as Canada, the USA and Finland mention wood as a basic resource for the bioeconomy $[9,10,119]$, but also in the German bioeconomy strategies, wood is regarded as the key feedstock next to agricultural biomass $[13,55]$. Wood production is generally seen as sustainable because less fertilizers and effort are needed for production than is the case with agricultural biomass, and it is possible to grow wood on poor soils that are not suitable for agriculture. In Germany, the guiding principle of wood management is the intergenerational and multifunctional management of wood resources supported by the nature protection and forest law $[120,121]$. However, does wood serve as an example for a sustainable bioeconomy, which helps to counter some of the above mentioned sustainability issues?

If the sustainable production of wood can be guaranteed, several sustainability-related advantages from its use can be expected: Because of fossil resource limits, negative environmental impacts of fossil resource extraction and transportation (cf. e.g., References [122,123]) and negative GHG-balances of fossil resource use, it is hypothesised that in most cases wood-based products are more sustainable in the long term. Wood-based products act as temporary carbon sinks due to the assimilation and storage of carbon in wood and therefore often show better GHG-balances than fossil resource substitutes [55,98].

Besides sustainability advantages of wood-based products in feedstock production, wood processing can be improved by enhancing resource productivity due to innovative technologies such as lignocellulosic biorefineries using organosolv pulping [98]. Moreover, transport efficiency can be increased and $\mathrm{CO}_{2}$-emissions of transportation can be reduced [99] by weight reduction of wood-based products or products with an admixture of wood compared to conventional products, e.g., concrete [111].

Despite an improvement in ecological performance of wood-based products over fossil-based ones in most cases, wood-based products do not automatically provide maximal sustainability. Rather, wood-based products represent a step towards more sustainable production and consumption. Even if the use of wood can enhance long-term economic sustainability, there are also sustainability risks when fossil resource inputs are substituted for wood without considering sustainability issues. These arise from several conflicts between competing claims on limited resources, such as land use conflicts, allocation conflicts, processing route conflicts or product conflicts (cf. [71]). Hence, an enabling function in governing the bioeconomy should always be completed by a limiting function (see Section 4 Transition challenges), which mainly has to focus on safeguarding the sustainability of the bioeconomy resource base, which means to support the use of wood at an adequate level. Supporting the use of wood at any cost would risk an overexploitation of natural wood resources and is in conflict with "natural" 
forest structures and thus with (i) nature protection aims, for instance biodiversity, (ii) climate protection aims, such as carbon assimilation and sequestration, (iii) ecosystem services, such as water and air purification, and (iv) other land uses, e.g., for tourism, recreation and leisure [32,71,124,125]. For the achievement of a maximal contribution to climate protection it may not be the solution to focus only the protection of domestic forests and land. Indeed, largescale wood imports would thwart the endeavours of GHG savings of wood use due to long and energy intensive transports [126]. Furthermore, as with other environmental schemes, in terms of the limiting function leakage effects have to be considered: besides the relocation of emissions and environmental risks of resource abstraction and production in countries with lower environmental standards, such as biodiversity loss due to land use changes or carbon leakage, (see e.g., References $[127,128]$ ), also economic "co-benefits" of the bioeconomy, such as employment, rural value creation, economic growth or impulses for technological progress could be forfeited [129]. All this calls for state incentives with a sense of proportion (see Section 4).

Our intermediate conclusion on sustainability is that it has to be the key concept behind the growing bioeconomy. Otherwise, the bioeconomy would only entail the substitution of fossil resources for bio-based resources without generating additional societal and ecological values and without contributing to climate mitigation and a long-term structural change. In the following section, we will outline how the bioeconomy can contribute to a transition towards sustainability.

\section{Transition Challenges: The Role of Government}

In the previous sections we fleshed out the most decisive sustainability conflicts of the bioeconomy that have to be considered when pursuing the bioeconomy as a vehicle towards sustainable development. This provides the knowledge base for the discussion of transition challenges and the role of governments for the bioeconomy in this section. We first outline the functions of bioeconomy governance and the pillars of bioeconomy transition. Further on, we demonstrate the need for state governance to adjust impeding market failures. We close this section stating challenges and recommendations for policy making.

The transition to bioeconomy has to be a transition to sustainability. For a successful outcome, state incentives are necessary, above all, to avoid a replication of mistakes from bioenergy. Therefore, the state has to take into account both, the enabling and limiting function of governance. But this is not easy as there are a lot of uncertainties relating to sustainability, such as safeguarding the resource base for the bioeconomy vs. biodiversity or the GHG-balance of products. This is not trivial because so far, the state focused on the enabling function as the substitution of resource inputs from fossil to renewable resources in the course of the bioeconomy is seen as a contribution to sustainability itself.

Despite that, the bioeconomy transition may be characterised as a path transition towards greater sustainability and allocative efficiency, and is expected to provide "co-benefits" to many societal aims (see Figure 1). Without question, the path transition towards a sustainable bioeconomy is a complex process that has to overcome the perpetuated lock-in into fossil resource-based production and consumption structures ("carbon lock-in", see Reference [130]). The state has the crucial role to design transition policies that enable the bioeconomy to expand by securing a level playing field for bio-based processes and products in relation to fossil resource-based ones (enabling function, cf. e.g., References $[119,131])$. But besides supporting the transition, policies must also ensure that sustainability is safeguarded all along the value chain of bio-based production processes (limiting function, cf. e.g., Reference [132]).

To reach the outlined political and societal aims, transition policies need to take account of three pillars of bioeconomy transition which are (1) substitution of fossil resources, (2) innovation in production processes and products, and (3) safeguarding sustainability within the bio-based value chain (see Figure 1). However, with these demands on the transformation of the economy, controversies and risk debates arise. Manifold controversies emphasise the fragile character of societal benefits assigned to a bioeconomy transition. An example is the controversy regarding economies of scale of production processes versus sufficient sustainable resource availability. 


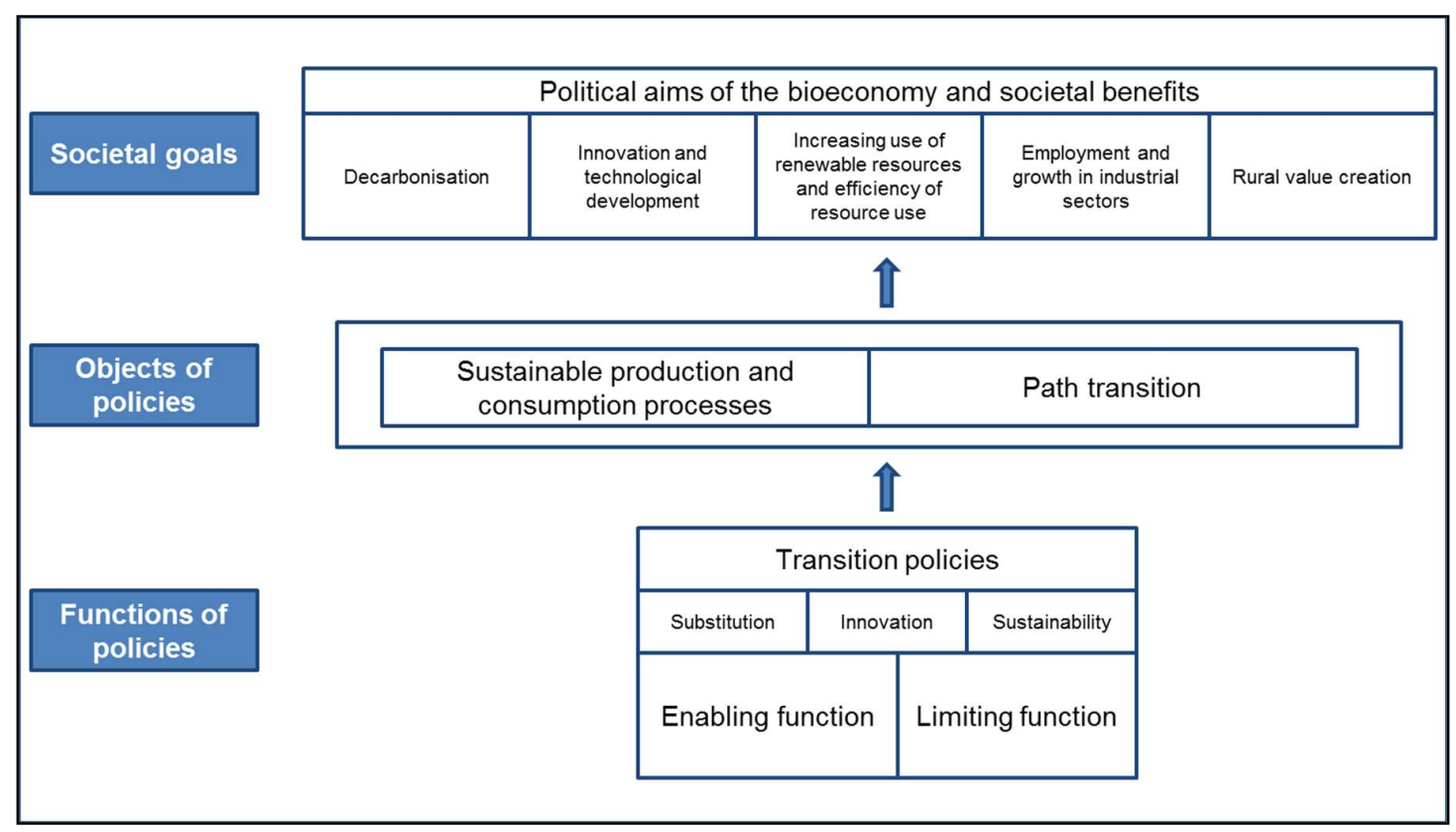

Figure 1. The role of bioeconomy governance (adapted from [133] with permission from Leal Filho et al. (Eds.), Towards a Sustainable Bioeconomy: Principles, Challenges and Perspectives; published by Springer Nature 2018).

Markets alone will not suffice to fulfil the enabling and limiting functions of bioeconomy governance because of a number of interacting market failures regarding extraction, processing and use of fossil resources [71,133,134]. Examples are GHG emissions, land degradation through mining, air pollution or waste generation which give rise to negative externalities, which, in the absence of policy measures, are insufficiently reflected in market prices [135,136]. Environmental externalities do not only distort competition between fossil resource-based and bio-based processes and products, but also between different bioeconomy production pathways, e.g., with regard to GHG balances, and impacts on biodiversity, water, and soil quality [137].

Moreover, investments in innovation and the deployment of innovative technologies give rise to knowledge and learning spillovers, which constitute a positive externality $[138,139]$. Investors are not able to appropriate the whole benefits of investments, which leads to an underinvestment in innovation and learning from a social perspective [140]. However, fossil resource-based technologies can benefit from past learning effects, increasing returns and network externalities; these interact with the specialised nature of investments to create a technological path dependency [141].

As the transition towards a sustainable bioeconomy requires innovation in technologies, processes and products $[61,88,142]$, especially immature renewable resource-based technologies have to progress down the learning curve to be competitive with fossil resource-based options in the long term (given fair competitive framework conditions). Additionally, innovations which decrease the impacts of renewable resource use on ecosystems are of high importance.

Nevertheless, a sustainable long-term oriented bioeconomy policy requires more: the challenge is to integrate bio-based substitutes into existing markets, where equivalent fossil-based products are well established [143]. In the view of the ubiquitous uncertainties related to bioeconomy pathways [144] the premature implementation of numerous new instruments to give a strong push to the bioeconomy does not appear promising. Rather, it is recommendable to combine a gradual strengthening of policies which increase the costs of fossil fuel use with targeted, sustainability-oriented support of innovative niche applications (e.g., green public procurement, labels). The governance of the bioeconomy as a "learning system" should gradually, but reliably set impulses for a sustainable transition path [145]. 
Additionally, policies need to address the limiting function and safeguard the sustainability of renewable resource use. It is especially important to examine to what extent existing policies on forestry, agriculture, the environment and trade need to be adapted in order to ensure sustainability. Moreover, waste policy needs to be adapted in order to set incentives for sustainable circular economy concepts [131]. A credible and consistent policy framework is necessary to address environmental externalities, support knowledge generation and learning, and overcome path dependencies [133].

A first step to address the enabling function of transition policy is to design a level playing field for biomass resources due to moderate "supply push" policies which seek to enhance the supply and reduce costs of bio-based raw materials and technologies, e.g., by providing funding for R\&D. This needs to be combined with "demand pull" policies which support the use of bio-based products and processes on the one hand and incentivise reductions in fossil resource use on the other hand (cf. [146,147], e.g., by cutting back direct and indirect subsidies for fossil-based pathways. But this is challenging because who would be interested in supporting a higher degree of internalisation of the external costs of fossil resource use that might lead to rising prices and a loss of purchasing power on the side of producers and consumers both? It is telling that renewable energy policy is mainly addressed through positive incentives for renewable energy use (e.g., feed-in tariffs, quotas with green certificate trading), rather than an increase in fossil fuel costs (given chronically low carbon allowances prices in the ailing European Emissions Trading System). The costs of positive incentives can be distributed across large and weakly organised social groups, making deployment support instruments politically more appealing than internalisation instruments such as emission taxes or emission trading schemes.

However, for the bioeconomy this constitutes less of a promising approach than for renewable energy technologies, given the much larger heterogeneity of actors, their levers and possible pathways and uncertainties about sustainability and costs of individual technologies, causing a lack of a broad interest coalition which could express a demand for such policies. Therefore, the state does not pursue adequate policies as this may cause high political costs [71]. Furthermore, the high degrees of uncertainty and complexity make demand-pull policy design for the bioeconomy particularly challenging [145]. Here, lessons from bioenergy policy can be learned: For example, the creation of a large-scale demand for biofuels through EU targets and national deployment support resulted in diverse environmental and social sustainability problems, while GHG mitigation costs remained comparatively high (see e.g., Reference [28]). This led to abrupt policy changes (e.g., the introduction of a limit on the contribution of food crop-based biofuels to EU targets) which decrease planning security for investors.

Therefore, when looking for answers as to where in bioeconomy value chains sustainability safeguarding functions of transition policies should intervene, lessons from bioenergy policy should be consulted. For example, sustainability requirements that are tied to specific end uses, such as sustainability standards for biofuels, can mitigate some sustainability risks (e.g., direct land use changes), but face severe limitations when it comes to addressing displacement and leakage effects which manifest as indirect land use changes (e.g., References [148,149]). With a growing demand for a large range of biomass-based applications, the importance of comprehensive, end use-independent requirements for sustainable land use increases. This requires adjustments in environmental framework conditions at national, EU and international levels (e.g., Reference [29]). Nonetheless, despite shortcomings, sustainability certification and safeguards in instruments which support the bioeconomy remain important measures, as long as more comprehensive reforms remain infeasible. Despite the fact that there are other levels of governance and other initiatives that may shape the bioeconomy, Fritsche and Iriarte [46] suggest to acknowledge and extend the binding sustainability requirements specifically targeted to biomass for bioenergy in developing a sustainable bioeconomy in order to avoid reinventing the wheel. For this, several indicators from bioenergy research, especially for the assessment of sustainable biomass production and use, can be derived, but as the bioeconomy covers more sectors and processes, additional indicators have to be identified (cf. e.g., Reference [150]). 
As a basic principle, a sustainable bioeconomy in the long term has to be economically self-sustaining through the provision of marketable products that are independent from long-term subsidies. Besides environmentally friendly feedstocks, technologies, processes and products as well as consumption and waste generation behaviour changes, the transition towards the bioeconomy has to follow a socially acceptable path, which means that affordability and access to products, a fair global distribution of resources and participation need to be addressed.

As bioeconomy innovations are fundamentally associated with uncertainty, the concept of responsible innovation addresses the aspects acceptability, sustainability and societal desirability in a transparent and interactive manner, whereas the outcome quality depends on the mutual understanding and level of knowledge of the actors [79]. In this light, responsible political decision making requires acknowledgement of all relevant actors. Policies should create opportunities for the society to become engaged $[47,68,151]$ as region-specific bottom-up approaches and social innovation matter in developing a sustainable bioeconomy $[79,132]$. Despite high variations between different regions in the EU, bio-based sectors contribute to economic development especially in regions affected by structural changes accelerated by the financial crisis [152].

At the moment, society is not taken on board (cf. $[50,153])$. Instead, there is a low public awareness of the bioeconomy and a need for inclusion of society in discussing the future pathways of the bioeconomy [151,154]. For a credible and reliable transition policy, societal acceptance and a broad coalition of interests which support associated policy changes is of crucial importance $[71,79,144]$. For this, positive framings highlighting the benefits of institutional and behavioural changes for human well-being are psychologically more effective than collapse warnings, which induce rather apathy instead of action towards sustainable development [81]. Supportively, implications from bioeconomy policies on businesses and the whole society need to be assessed.

A good example is the increasing demand for wood buildings. It shows a growing awareness of current environmental problems and the willingness to counteract, but several existing barriers need to be removed to reach more people to ensure further progress $[101,155]$. This illustrates the need for a minimum level of demand for sustainability policies for an adequate supply of such policies or rather the interplay of supply and demand for policies, what also holds true for other applications in the bioeconomy sector (cf. [71] for bioeconomy policies). This does not only mean political adjustments in single application fields, such as bio-based chemicals or plastics or textiles, but a coherent approach based on sustainability principles that ensures economic returns, avoid environmental problems and meet socioeconomic expectations [156]. Indeed, it requires coordination and coherence between different application fields in the bioeconomy sector to secure the sustainability of the resource base and to enable learning and spillover effects between the various application fields of the bioeconomy (cf. [65]). In this light, incentives for the formation and development of industrial symbiosis in the bioeconomy network can support the integration of different processes and material streams and thus, save costs and mitigate environmental impacts of the production system [157].

Furthermore, sufficiency policy is needed to complement the efficiency policy measures to avoid rebound effects $[91,158,159]$. Only in this manner a long-term sustainable bioeconomy can be realized which is likewise able to release ambivalences and uncertainties regarding bio-based products (cf. $[160,161]$ ) and to create credibility and acceptance for the bioeconomy. This would enable an increase of the necessary critical mass of consumers and producers that is needed for competitiveness and a long-term self-sustaining path transition towards a sustainable bioeconomy (cf. [71]). Ultimately, the key to economic sustainability lies in ecological and social responsibility and sustainability (cf. [119]).

\section{Key Messages and Recommendations: No Bioeconomy without Sustainability!}

We conclude that transitioning to a sustainable bioeconomy entails much more than only substituting fossil inputs by renewable resources, as presented in Section 4. As previously outlined in Section 3, the bioeconomy is also not per se the answer to the sustainability challenges; rather new risks may emerge. Therefore, new and specific guard rails for sustainability are needed: 
(1) The sustainability conflicts of the bioeconomy outlined in Section 3 illustrate that the bioeconomy can be a contribution to sustainable development and the SDGs, if specific guardrails are observed. Regarding to the transition challenges towards a sustainable bioeconomy demonstrated in Section 4, state governance is necessary to reduce competitive drawbacks (enabling perspective) and, above all, to safeguard sustainability in all dimensions (limiting perspective). Mere input substitution may entail welfare losses. However, as a response to the criticism in recent years, the bioeconomy concept has been linked to sustainable development and shifted from a technology-to a more society-centred focus, the doubts remain, if sustainability aspects are addressed satisfactorily in political strategies and policymaking for a transition towards a sustainable bioeconomy development.

(2a) It is not merely about "the bioeconomy"; but "the sustainable bioeconomy": Unconditionally, sustainability has to be an inherent part of the bioeconomy definition. Based on the overview of bioeconomy definitions, framings and conceptualisations in Section 2 and to strengthen the earliest possible awareness of potential sustainability risks outlined in Section 3, we suggest a definition for the bioeconomy such as "bio-and technology-based circular economy, which is sustainable in resource production and conversion, consumption as well as waste management". Referring to our intermediate conclusion from Section 3, sustainability has to be the key concept behind the bioeconomy because otherwise, only fossil resources would be substituted for bio-based ones without generating additional societal and ecological values and without contributing to climate mitigation and a long-term structural change.

(2b) Therefore, an "industrial policy-centered vision" and a "normative vision" have to be distinguished. As presented in Section 2, the positive understanding of the bioeconomy as an umbrella term for bio-based sectors of the economy in an industrial policy-centered vision currently dominates the political strategies and scientific and public debates. Too little attention is paid to the normative vision where the bioeconomy is part of a broader path transition from a fossil-based "throughput economy" towards a sustainable circular flow economy based on renewable resources.

(3) The substitution of fossil resources alone does not guarantee sustainability as already shown in the lessons learnt from bioenergy in Section 3. Indeed, it requires

1. Sustainability of the resource base (e.g., bioenergy: real GHG-savings)

2. Sustainability (in particular environmental compatibility) of processes and products, especially by 3. circular processes.

The rise of the demand for bio-based products will further increase the pressure on limited biomass and land resources and thus, will cause several sustainability conflicts, as already seen in the context of bioenergy. As the prefix "Bio" has lost its innocence, demand growth for bio-based products will only be attainable, if sustainability as the key in bioeconomy supply chains is noticeable for consumers. Thus far, potential negative impacts of biomass use on a massive scale shall be reduced by means of novel technologies, but to expect innovative technologies to be a magic bullet solving all problems is a disastrous misbelief. Instead, innovations are both, part of the problem, but also part of the solution to the sustainability problems.

Sustainability conflicts and transition challenges towards a sustainable bioeconomy need to be discussed and carefully thought out. A sustainable bioeconomy is only feasible if, and only if, all three pillars of sustainability are taken into account from the very beginning and if synergies between these pillars can be achieved. In doing so, usually none of these three pillars is maximized, but instead the optimal combination of these pillars is prospected and implemented. Ultimately, the key to economic sustainability lies in ecological and social responsibility and sustainability.

(4) Numerous, even new challenges and trade-offs resulting from a bio-based economy have to be solved within the scope of sustainability. Moreover, new types of technologies with standard technology assessments are necessary and massive, multi-dimensional insecurities have to be overcome. While niche applications are still simple, the upscaling of resource streams is the most challenging task as spatial and temporal high and variable biomass streams can proof problematic, as outlined 
in Section 3. For this, a search and correction process has to be organised. Usually, markets perform these tasks in a sufficient manner, but as demonstrated in Section 4, various market failures in the bioeconomy distort fair comparisons of alternatives, the state has to create a selection environment to guide these search processes as long as a fair basic conditions exist. In the long-term, the path transition has to be self-enforcing by generating competitive products and processes, and also by fostering a change of consumption patterns.

(5) Due to a great number of uncertainties (e.g., regarding sustainability) the transition towards a bioeconomy requires a gradual, adaptive governance approach that allows for policy learning as presented in Section 4. At the same time, a credible commitment to an overall path transition is required to generate the planning security necessary to initiate the inevitable investments and behavioural changes.

Bioeconomic policy has a twofold role: On the one hand, it has the potential to create a level playing field for bio-based processes and products (enabling function). This requires addressing relevant market failures such as climate and other environmental externalities that distort competition between fossil and bio-based alternatives. In addition, it is important to overcome path dependencies in favour of the existing fossil resource-based "flow economy". On the other hand, bioeconomy policy must also fulfil a restriction function and ensure the sustainability of increased use of biomass (limiting function).

This calls for "bioeconomy policy", as a genuine field of policy, and "bioeconomy law", as a discrete field of law, in order to be able to send non-conflicting signals from the state sector. This could enable various actions in the individual application fields of the bioeconomy, but also coordination and reconciliation between the application fields, which is necessary to avoid sustainability risks and to enable learning effects and spillovers. For this, we recommend to gradually develop and extend a combination of existing instruments, including internalisation instruments, focused support of niches and R\&D support. For instance, material-focused climate policies which reward the use of less resource-and energy-intensive materials such as wood-based materials are one possibility to achieve climate protection goals, for instance by supporting a wood-based bioeconomy. Furthermore, to support a well-functioning bioeconomy innovation system, a specific policy setting including a mix of "technology push"- and direct and indirect "demand pull"-measures, standardisation and labelling is advisable.

To conclude, the realization of a genuine sustainable bioeconomy needs more than lip service and research funding. Instead of mere symbol politics or sectoral policies, transformation policies promoting sustainable development are needed. Otherwise, attempts to put the bioeconomy into practice might peter out and a transition towards sustainable development would be unduly delayed.

Author Contributions: Conceptualization: E.G. and N.P.; investigation: N.P. and N.H.; writing一original draft preparation: N.P.; writing—review and editing: E.G. and N.H.; supervision: E.G.

Funding: This research was funded by German Federal Ministry of Education and Research (BMBF), grant number 031A078A. The APC was funded by Helmholtz Centre for Environmental Research GmbH-UFZ.

Conflicts of Interest: The authors declare no conflict of interest.

\section{References}

1. Rockström, J.; Steffen, W.; Noone, K.; Persson, A.; Chapin, F.S., III; Lambin, E.F.; Lenton, T.M.; Scheffer, M.; Folke, C.; Schellnhuber, H.J.; et al. A safe operating space for humanity. Nature 2009, 461, 472-475. [CrossRef]

2. European Commission (EC). Innovating for Sustainable Growth: A Bioeconomy for Europe; EU Publications: Brussels, Belgium, 2012.

3. Von Braun, J. Bioökonomie-auf dem Weg zu nachhaltigem Wirtschaften. In 5. Jahrbuch Nachhaltige Ökonomie 2016/2017. Im Brennpunkt Ressourcenwende-Transformation zu Einer Ressourcenleichten Gesellschaft; Rogall, H., Ed.; Metropolis-Verlag: Marburg, Germany, 2016. 
4. Lokko, Y.; Heijde, M.; Schebesta, K.; Scholtes, P.; Van Montagu, M.; Giacca, M. Biotechnology and the bioeconomy-Towards inclusive and sustainable industrial development. New Biotechnol. 2018, 40, 5-10. [CrossRef] [PubMed]

5. Bell, J.; Paula, L.; Dodd, T.; Németh, S.; Nanou, C.; Mega, V.; Campos, P. EU ambition to build the world's leading bioeconomy-Uncertain times demand innovative and sustainable solutions. New Biotechnol. 2018, 40, 25-30. [CrossRef]

6. OECD. What External Factors Will Drive the Bioeconomy to 2030? The Bioeconomy to 2030: Designing a Policy Agenda; OECD Publishing: Paris, France, 2009.

7. De Besi, M.; McCormick, K. Towards a Bioeconomy in Europe: National, Regional and Industrial Strategies. Sustainability 2015, 7, 10461-10478. [CrossRef]

8. Staffas, L.; Gustavsson, M.; McCormick, K. Strategies and Policies for the Bioeconomy and Bio-Based Economy: An Analysis of Official National Approaches. Sustainability 2013, 5, 2751-2769. [CrossRef]

9. German Bioeconomy Council. Bioeconomy Policy. Synopsis and Analysis of Strategies in the G7; Office of the Bioeconomy Council: Berlin, Germany, 2015.

10. German Bioeconomy Council. Bioeconomy Policy (Part II): Synopsis of National Strategies around the World; Office of the Bioeconomy Council: Berlin, Germany, 2015.

11. German Bioeconomy Council. Bioeconomy Policy (Part III): Update Report of National Strategies around the World; Office of the Bioeconomy Council: Berlin, Germany, 2018.

12. European Commission (EC). Horizon 2020-The Framework Programme for Research and Innovation. COM(2011) 808 Final; European Commission (EC): Brussels, Belgium, 2011.

13. German Federal Ministry of Education and Research (BMBF). Nationale Forschungsstrategie BioÖkonomie 2030-Unser Weg zu einer bio-basierten Wirtschaft; BMBF: Bonn, Germany, 2010.

14. German Federal Ministry of Education and Research (BMBF). Auftaktveranstaltung zur Weiterentwicklung der Bioökonomie-Strategie. Available online: https://www.bmbf.de/de/auftaktveranstaltung-zur-weiterentwicklungder-biooekonomie-strategie-2574.html (accessed on 26 August 2016).

15. German Federal Ministry of Education and Research (BMBF). Forschung für Eine Biobasierte Wirtschaft. Erfolge und Herausforderungen für die Bioökonomie in Deutschland; Updated German Bioeconomy Research Strategy; BMBF: Berlin, Germany, 2017.

16. Bioeconomy Science Center (BioSC). Sustainable Bioeconomy: Concept and Relevance. Available online: https://www.biosc.de/sustainable_bioeconomy_en. (accessed on 29 March 2019).

17. Vainio, A.; Ovaska, U.; Varho, V. Not so sustainable? Images of bioeconomy by future environmental professionals and citizens. J. Clean. Prod. 2019, 210, 1396-1405. [CrossRef]

18. Ober, S. Nachhaltigkeit in der Bioökonomie. Zusammenfassung und Thesen als Ergebnis eines Workshops auf Vilm 2013; NABU_Bundesverband Naturschutzbund Deutschland (NABU) e.V.: Berlin, Germany, 2014.

19. Unmüßig, B. Bioeconomy-A dead end. Rural 21 2014, 3, 34-35. Available online: https://www.rural21.com/ uploads/media/rural2014_03-S34-35.pdf (accessed on 29 March 2019).

20. Bezama, A. Understanding the systems that characterise the circular economy and the bioeconomy. Waste Manag. Res. 2018, 36, 553-554. [CrossRef]

21. Pfau, S.F.; Hagens, J.E.; Dankbaar, B.; Smits, A.J.M. Visions of Sustainability in Bioeconomy Research. Sustainability 2014, 6, 1222-1249. [CrossRef]

22. Albrecht, S.; Gottschick, M.; Schorling, M.; Stirn, S. Bioökonomie am Scheideweg. Industrialisierung von Biomasse oder nachhaltige Produktion? GAIA 2012, 21/1, 33-37. [CrossRef]

23. Schmid, O.; Padel, S.; Levidow, L. The bio-economy concept and knowledge base in a public goods and farmer perspective. Bio-Based Appl. Econ. 2012, 1, 47-63. [CrossRef]

24. Levidow, L.; Birch, K.; Papaioannou, T. EU agri-innovation policy: two contending visions of the bio-economy. Crit. Pol. Stud. 2012, 6, 40-65. [CrossRef]

25. European Commission. Biomass Action Plan; COM(2005) 628 Final; EU Commission: Brussels, Belgium, 2005.

26. German Federal Ministry for the Environment, Nature Conservation and Nuclear Safety (BMU) \& German Federal Ministry for Food, Agriculture and Consumer Protection (BMELV). Nationaler Biomasseaktionsplan für Deutschland. Beitrag der Biomasse für eine nachhaltige Energieversorgung; BMELV: Berlin, Germany, 2010.

27. Nuffield Council on Bioethics. Biofuels: Ethical Issues; Nuffield Council on Bioethics: London, UK, 2011.

28. German Advisory Council on Global Change. Future Bioenergy and Sustainable Land Use; WBGU: Berlin, Germany, 2008. 
29. German Advisory Council on the Environment. Climate Change Mitigation by Biomass; Special Report; SRU: Berlin, Germany, 2007.

30. Hagemann, N.; Walde, A.; Purkus, A.; Pannicke, N.; Gawel, E. Public perception of the bioeconomy-A content analysis of media articles in Germany. J. Clean. Prod. Submitted.

31. Lewandowski, I. Securing a sustainable biomass supply in a growing bioeconomy. Glob. Food Secur. 2015, 6, 34-42. [CrossRef]

32. Müller, A.; Weigelt, J.; Götz, A.; Schmidt, O.; Lobos Alva, I.; Matuschke, I.; Ehling, U.; Beringer, T. The Role of Biomass in the Sustainable Development Goals: A Reality Check and Governance Implications; IASS Working Paper Prepared by the Renewable Resources and the Sustainable Development Goals Forum, Global Soil Forum, Institute for Advanced Sustainability Studies e. V. (IASS); Institute for Advanced Sustainability Studies e. V. (IASS): Potsdam, Germany, 2015. [CrossRef]

33. Landeweerd, L.; Surette, M.; van Driel, C. From petrochemistry to biotech: A European perspective on the bio-based economy. Interface Focus 2011, 1, 189-195. [CrossRef]

34. Scarlat, N.; Dallemand, J.-F.; Monforti-Ferrario, F.; Nita, V. The role of biomass and bioenergy in a future bioeconomy: Policies and facts. Environ. Dev. 2015, 15, 3-34. [CrossRef]

35. Rosegrant, M.W.; Ringler, C.; Zhu, T.; Tokgoz, S.; Bhandary, P. Water and food in the bioeconomy: challenges and opportunities for development. Agric. Econ. 2013, 44s1, 139-150. [CrossRef]

36. Templer, R.; van der Wielen, L. Biorenewables, the bio-based economy and sustainability. Interface Focus 2011, 1, 187-188. [CrossRef]

37. Ten Bos, R.; van Dam, J.E.G. Sustainability, polysaccharide science, and bio-economy. Carbohydr. Polym. 2013, 93, 3-8. [CrossRef] [PubMed]

38. Sillanpää, M.; Ncibi, C. A Sustainable Bioeconomy. The Green Industrial Revolution, 1st ed.; Springer: Cham, Switzerland, 2017. [CrossRef]

39. Gottwald, F.-T.; Krätzer, A. Irrweg Bioökonomie. Kritik an einem totalitären Ansatz., 1st ed.; Suhrkamp Verlag: Berlin, Germany, 2014.

40. Wagner, H.-G. Bioökonomie-Über die Pervertierung eines grünen Paradigmas. Zeitschrift für Sozialökonomie (ZfSÖ) 2015, 52, 57-68.

41. Birch, K.; Levidow, L.; Papaioannou, T. Sustainable capital? The neoliberalization of nature and knowledge in the European "knowledge-based bio-economy". Sustainability 2010, 2, 2898-2918. [CrossRef]

42. Goven, J.; Pavone, V. The Bioeconomy as a Political Project: A Polanyian Analysis. Sci. Technol. Hum. Value 2015, 40, 302-337. [CrossRef]

43. Peltomaa, J. Drumming the Barrels of Hope? Bioeconomy Narratives in the Media. Sustainability 2018, 10, 4278. [CrossRef]

44. Bugge, M.; Hansen, T.; Klitkou, A. What Is the Bioeconomy? A Review of the Literature. Sustainability 2016, 8, 691. [CrossRef]

45. Ramcilovic-Suominen, S.; Pülzl, H. Sustainability and Sustainable Development-'Selling points' for the EU Bioeconomy? J. Clean. Prod. 2018, 172, 4170-4180. [CrossRef]

46. Fritsche, U.R.; Iriarte, L. Sustainability Criteria and Indicators for the Bio-Based Economy in Europe: State of Discussion and Way Forward. Energies 2014, 7, 6825-6836. [CrossRef]

47. McCormick, K.; Kautto, N. The bioeconomy in Europe: An overview. Sustainability 2013, 5, $2589-2608$. [CrossRef]

48. Resolution adopted by the General Assembly on 16 September 2005. Available online: https://www.un.org/en/ development/desa/population/migration/generalassembly/docs/globalcompact/A_RES_60_1.pdf (accessed on 22 May 2019).

49. Thatcher, A. Theoretical definitions and models of sustainable development that apply to human factors and ergonomics. Conference Paper. In Proceedings of the 11th International Symposium on Human Factors in Organisational Design and Management and the 46th Annual Nordic Ergonomics Society Conference, Copenhagen, Denmark, 17-20 August 2014; Volume 1-2.

50. Grefe, C. Global Gardening. Bioökonomie-Neuer Raubbau oder Wirtschaftsform der Zukunft? 1st ed.; Verlag Antje Kunstmann GmbH: München, Germany, 2016.

51. Von Braun, J. Bioeconomy and sustainable development-dimensions. Rural 21 2014, 2, 6-9.

52. Birner, R. Bioeconomy Concepts. In Bioeconomy. Shaping the Transition to a Sustainable, Biobased Economy, 1st ed.; Lewandowski, I., Ed.; Springer: Cham, Switzerland, 2018. [CrossRef] 
53. Patermann, C.; Aguilar, A. The origins of the bioeconomy in the European Union. New Biotechnol. 2018, 40, 20-24. [CrossRef]

54. European Commission. New Perspectives on the Knowledge-Based Bioeconomy; Conference Report; European Commission: Brussels, Belgium, 2005.

55. German Federal Ministry of Food and Agriculture (BMEL). Nationale Politikstrategie Bioökonomie; BMEL: Berlin, Germany, 2014.

56. Pülzl, H.; Kleinschmit, D.; Arts, B. Bioeconomy-an emerging meta-discourse affecting the forest discourse. Scan. J. For. Res. 2014, 29, 386-393. [CrossRef]

57. Levidow, L.; Birch, K.; Papaioannou, T. Divergent paradigms of European agro-food innovation: The knowledgebased bio-economy (KBBE) as an R \& D agenda. Sci. Technol. Hum. Values 2013, 38, 94-125. [CrossRef]

58. En Route to the Knowledge-Based Bio-Economy. Available online: https://dechema.de/dechema_media/ Downloads/Positionspapiere/Cologne_Paper-p-20000945.pdf (accessed on 22 May 2019).

59. Richardson, B. From a fossil-fuel to a biobased economy: the politics of industrial biotechnology. Environ. Plan. C Gov. Pol. 2012, 30, 282-296. [CrossRef]

60. German Federal Government. Deutsche Nachhaltigkeitsstrategie; Neuauflage 2016; German Federal Government: Berlin, Germany, 2017.

61. German Bioeconomy Council. Innovation Bioökonomie: Forschung und Technologieentwicklung für Ernährungssicherung, nachhaltige Ressourcennutzung und Wettbewerbsfähigkeit; Bioeconomy Council: Berlin, Germany, 2010.

62. European Commission (EC). The Role of Science, Technology and Innovation Policies to Foster the Implementation of the Sustainable Development Goals (SDGs). Report of the Expert Group "Follow-up to Rio+20, notably the SDGs"; European Commission: Brussels, Belgium, 2015.

63. Siebert, A.; Bezama, A.; O'Keeffe, S.; Thrän, D. Social life cycle assessment: in pursuit of a framework for assessing wood-based products from bioeconomy regions in Germany. Int. J. Life Cylce Ass. 2018, 23, 651-662. [CrossRef]

64. Birch, K. Emergent Imaginaries and Fragmented Policy Frameworks in the Canadian Bio-Economy. Sustainability 2016, 8, 1007. [CrossRef]

65. Kleinschmit, D.; Lindstad, B.H.; Thorsen, B.J.; Toppinen, A.; Roos, A.; Baardsen, S. Shades of green: a social scientific view on bioeconomy in the forest sector. Scan. J. For. Res. 2014, 29, 402-410. [CrossRef]

66. El-Chichakli, B.; von Braun, J.; Lang, C.; Barben, D.; Philp, J. Five cornerstones of a global bioeconomy. Nature 2016, 535, 221-223. [CrossRef]

67. Ingrao, C.; Bacenetti, J.; Bezama, A.; Blok, V.; Goglio, P.; Koukios, E.G.; Lindner, M.; Nemecek, T.; Siracusa, V.; Zabaniotou, A.; et al. The potential roles of bio-economy in the transition to equitable, sustainable, post fossil-carbon societies: Findings from this virtual special issue. J. Clean. Prod. 2018, 204, 471-488. [CrossRef]

68. Schütte, G. What kind of innovation policy does the bioeconomy need? New Biotechnol. 2018, 40 Pt A, $82-86$. [CrossRef]

69. Future Earth. The Contribution of Science in Implementing the Sustainable Development Goals; German Committee Future Earth: Stuttgart, Germany, 2016.

70. Zeug, W.; Bezama, A.; Moesenfechtel, U.; Jähkel, A.; Thrän, D. Stakeholders' Interests and Perceptions of Bioeconomy Monitoring Using a Sustainable Development Goal Framework. Sustainability 2019, 11, 1511. [CrossRef]

71. Pannicke, N.; Gawel, E.; Hagemann, N.; Purkus, A.; Strunz, S. The political economy of fostering a wood-based bioeconomy in Germany. Ger. J. Agric. Econ. 2015, 64, 224-243.

72. Frondel, M.; Peters, J. Biodiesel: A new Oildorado? Energy Pol. 2007, 35, 1675-1684. [CrossRef]

73. Henke, J.M.; Klepper, G. Biokraftstoffe: Königsweg für Klimaschutz, Profitable Landwirtschaft und Sichere Energieversorgung? Institut für Weltwirtschaft: Kiel, Germany, 2006.

74. European Parliament and Council of the European Union. Directive (EU) 2015/1513 of the European Parliament and of the Council of 9 September 2015 amending Directive 98/70/EC relating to the quality of petrol and diesel fuels and amending Directive 2009/28/EC on the promotion of the use of energy from renewable sources. Off. J. Eur. Uni 2015, L 239, 1-29.

75. Pfeiffer, D.; Thrän, D. One Century of Bioenergy in Germany: Wildcard and Advanced Technology. Chem. Ingenieur Technik 2018, 90, 1676-1698. [CrossRef] 
76. Zinke, H.; El-Chichakli, B.; Dieckhoff, P.; Wydra, S.; Hüsing, B. Bioökonomie für die Industrienation. Ausgangslage für Biobasierte Innovationen in Deutschland Verbessern; German Bioeconomy Council: Berlin, Germany, 2016.

77. European Commission (EC). A sustainable Bioeconomy for Europe. Strengthening the Connection between Economy, Society and the Environment; Updated Bioeconomy Strategy; EC: Brussels, Belgium, 2018.

78. Lamers, P.; Searcy, E.; Hess, J.R. Transition Strategies: Resource Mobilization through Merchandisable Feedstock Intermediates. In Developing the Global Bioeconomy. Technical, Market, and Environmental Lessons from Bioenergy, 1st ed.; Lamers, P., Searcy, E., Hess, J.R., Stichnothe, H., Eds.; Academic Press: Cambridge, MA, USA, 2016. [CrossRef]

79. Pyka, A.; Prettner, K. Economic Growth, Development, and Innovation: The Transformation Towards a Knowledge-Based Bioeconomy. In Bioeconomy. Shaping the Transition to a Sustainable, Biobased Economy, 1st ed.; Lewandowski, I., Ed.; Springer: Cham, Switzerland, 2018. [CrossRef]

80. Costanza, R.; Graumlich, L.J.; Steffen, W. Sustainability or Collapse? An Integrated History and Future of People on Earth; Dahlem Workshop Reports; MIT Press: Cambridge, MA, USA, 2007.

81. Strunz, S.; Marselle, M.; Schröter, M. Leaving the "sustainability or collapse" narrative behind. Sustain. Sci. 2019. [CrossRef]

82. Gonzales, N.C. Regulation of bio based economy. The challenges of the local innovation in governance. In Proceedings of the Conference Paper for 5th AIEAA-Conference, The Changing Role of Regulation in the Bio-Based Economy, Bologna, Italy, 16-17 June 2016.

83. Forum Umwelt und Entwicklung. Goldgräberstimmung -Bioökonomie zwischen Welthunger und Rohstoffalternativen. Rundbrief 04/2014; Forum Umwelt und Entwicklung: Berlin, Germany, 2014; ISSN 1864-0982.

84. Darby, M.R.; Karni, E. Free competition and the optimal amount of fraud. J. Law Econ. 1973, 16, 67-88. [CrossRef]

85. Ranacher, L.; Höfferer, K.; Lettner, M.; Hesser, F.; Stern, T.; Rauter, R.; Schwarzbauer, P. What would potential future opinion leaders like to know? An explorative study on the perceptions of four wood-based innovations. Die Bodenkultur J. Land Manag. Food Environ. 2018, 69, 47-59. [CrossRef]

86. Koppejan, D.; Asveld, L. The public debate: an accumulation of controversies. In Getting to the Core of the Bio-Economy: A Perspective on the Sustainable Promise of Biomass; Asveld, L., van Est, R., Stemerding, D., Eds.; Rathenau Instituut: The Hague, The Netherlands, 2011; pp. 55-85.

87. Vandermeulen, V.; Van der Steen, M.; Stevens, C.V.; Van Huylenbroeck, G. Industry expectations regarding the transition towards a biobased economy. Biofuels Bioprod. Bioref. 2012, 6, 453-464. [CrossRef]

88. Carus, M.; Raschka, A.; Fehrenbach, H.; Rettenmaier, N.; Dammer, L.; Köppen, S.; Thöne, M.; Dobroschke, S.; Diekmann, L.; Hermann, A.; et al. Ökologische Innovationspolitik-Mehr Ressourceneffizienz und Klimaschutz durch nachhaltige stoffliche Nutzungen von Biomasse; Umweltbundesamt: Dessau-Roßlau, Germany, 2014.

89. Pacini, H.; Assunção, L.; van Dam, J.; Toneto, R. The price for biofuels sustainability. Energy Pol. 2013, 59, 898-903. [CrossRef]

90. Pietzsch, J. (Ed.) Bioökonomie für Einsteiger, 1st ed.; Springer: Berlin, Germany, 2017.

91. Keil, R. Ressourceneffizienz, Ressourcensubstitution und biologische Vielfalt. In Ressourcen Schonen-Biologische Vielfalt Erhalten. Chancen und Risiken von Rohstoffsubstitutionen für die Biologische Vielfalt, 1st ed.; Keil, R., Robinet, K., Todt, A., Eds.; Oekom: München, Germany, 2015.

92. Santarius, T. Der Rebound-Effekt: ein blinder Fleck der sozial-ökologischen Gesellschaftstransformation. GAIA 2014, 23/2, 109-117. [CrossRef]

93. Leal Filho, W. Bioeconomy Meets the Circular Economy: The RESYNTEX and FORCE Projects. In Towards a Sustainable Bioeconomy: Principles, Challenges and Perspectives, 1st ed.; Leal Filho, W., Pociovalisteanu, D.M., Borges de Brito, P., Borges de Lima, I., Eds.; World Sustainability Series; Springer International Publishing: Cham, Swtizerland, 2018. [CrossRef]

94. Arnold, K.; von Geibler, J.; Bienge, K.; Stachura, C.; Borbonus, S.; Kristof, K. Kaskadennutzung von nachwachsenden Rohstoffen: Ein Konzept zur Verbesserung der Rohstoffeffizienz und Optimierung der Landnutzung; Wuppertal Institut für Klima, Umwelt, Energie GmbH: Wuppertal, Germany, 2009; ISSN 0949-5266.

95. Lindner, M.; Hanewinkel, M.; Nabuurs, G.-J. How Can a Forest-Based Bioeconomy Contribute to Climate Change Adaptation and Mitigation. In Towards a Sustainable European Forest-Based Bioeconomy-Assessment and the Way Forward, 1st ed.; Winkel, G., Ed.; European Forest Institute: Joensuu, Finland, 2017.

96. German Advisory Council on Global Change (WBGU). Der Umzug der Menschheit: Die Transformative Kraft der Städte. Zusammenfassung; WBGU: Berlin, Germany, 2016. 
97. Müller, D.B.; Liu, G.; Løvik, A.N.; Modaresi, R.; Pauliuk, S.; Steinhoff, F.S.; Brattebø, H. Carbon Emissions of Infrastructure Development. Environ. Sci. Technol. 2013, 47, 11739-11746. [CrossRef]

98. Cheng, H.; Wang, L. Lignocelluloses Feedstock Biorefinery as Petrorefinery Substitutes. In Biomass Now-Sustainable Growth and Use; Matovic, M.D., Ed.; 2013; Available online: https://www.intechopen.com/books/ biomass-now-sustainable-growth-and-use/lignocelluloses-feedstock-biorefinery-as-petrorefinery-substitutes (accessed on 29 March 2019). [CrossRef]

99. Karus, M.; Kaub, M. Naturfasern für die Europäische Automobilindustrie; Nova-Institut: Hürth, Germany, 2001.

100. German Advisory Council on Agricultural Policy. Nutrition and Consumer Protection (WBA) and German Advisory Council on Forest Policy (WBW). Klimaschutz in der Land-und Forstwirtschaft sowie den nachgelagerten Bereichen Ernährung und Holzverwendung; InTech Open: Berlin, Germany, 2016.

101. Ludwig, G.; Purkus, N.; Pannicke, N.; Gawel, E. Bauen mit Holz als Beitrag zum Klima-und Ressourcenschutz-Status quo des Rechtsrahmens und Gestaltungsvorschläge. Die öffentliche Verwaltung (DÖV) 2017, 23, 985-995.

102. Mantau, U.; Döring, P.; Hiller, D. Holzeinsatz im Bauwesen-Verwendungsstrukturen nach Gebäuden und Gewerken. In Holzverwendung im Bauwesen-Eine Marktstudie im Rahmen der "Charta für Holz"; Weimar, H., Jochem, D., Eds.; Thünen Report 9; Thünen: Hamburg, Germany, 2013.

103. Informationsdienst Holz. Available online: http://informationsdienst-holz.de/index.php?id=66\&tx_locator_ pi1[storeUid]=136 (accessed on 29 March 2019).

104. Waugh Thistleton. Available online: http://www.waughthistleton.com/project/murray-grove/ (accessed on 29 March 2019).

105. Dederich, L. Resource Efficient Buildings. Innovative Biobased Products: Opportunities for Substituting Non-Renewable Resources. In Proceedings of the Presentation on G7-Alliance on Resource Efficiency, Berlin, Germany, 24 November 2015.

106. German Agency for Renewable Resources (FNR). Marktanalyse Nachwachsende Rohstoffe; Schriftenreihe Nachwachsende Rohstoffe (34): Gülzow-Prüzen, Germany, 2014.

107. Brandner, R.; Flatscher, G.; Ringhofer, A.; Schickhofer, G.; Thiel, A. Cross laminated timber (CLT): overview and development. Eur. J. Wood Prod. 2016, 74, 331-351. [CrossRef]

108. van de Kuilen, J.W.G.; Ceccotti, A.; Xia, Z.; He, M. Very Tall Wooden Buildings with Cross Laminated Timber. Proc. Eng. 2011, 14, 1621-1628. [CrossRef]

109. Wehsener, J.; Werner, T.-E.; Hartig, J.; Haller, P. Advancements for the Structural Application of Fiber-Reinforced Moulded Wooden Tubes. In Materials and Joints in Timber Structures-Recent Developments of Technology; Aicher, S., Reinhardt, H.-W., Garrecht, H., Eds.; Springer: Amsterdam, The Netherlands, 2014.

110. Lettau-Tischel, S. Dresden setzt Weltstandards-Leichtbau: Elektromobilität verbindet-Region im Schaufenster Elektromobilität Bayern-Sachsen. Präsentation, Amt für Wirtschaftsförderung Dresden, Germany. 2012. Available online: http://www.mfd-dresden.com/fileadmin/MFD-Dateien/Bilder/PDF/Dresden_Leichtbau_ MFD_2012_deutsch.pdf (accessed on 26 March 2015).

111. Krippner, R. Untersuchungen zu Einsatzmöglichkeiten von Holzleichtbeton im Bereich von Gebäudefassaden. Ph.D. Thesis, Technische Universität München, München, Germany, 2004.

112. Homami, S.S.; Seydei, M.K.; Moradi, S. Preparation of Wood Plastic Composite from Polyethylene and Bagasse. Middle-East J. Sci. Res. 2013, 14, 453-455.

113. Carus, M.; Eder, A.; Dammer, L.; Korte, H.; Scholz, L.; Essel, R.; Breitmayer, E.; Barth, M. Wood-Plastic Composites (WPC) and Natural Fibre Composites (NFC): European and Global Markets 2012 and Future Trends in Automotive and Construction. WPC/NFC Market Study 2014-10 (Update 2015-06). Nova market study 2015. Available online: https://compositesuk.co.uk/system/files/documents/WPC-NFC-Market-StudyShort-Verson\%202015.pdf (accessed on 10 May 2019).

114. Peças, P.; Carvalho, H.; Salman, H.; Leite, M. Natural Fibre Composites and Their Applications: A Review. J. Comp. Sci. 2018, 2, 66. [CrossRef]

115. DeFrance, K.J.; Hoare, T.; Cranston, E.D. Review of Hydrogels and Aerogels Containing Nanocellulose. Chem. Mater. 2017, 29, 4609-4631. [CrossRef]

116. Kamm, B.; Kamm, M.; Schmidt, M.; Hirth, T.; Schulze, M. Lignocellulose-based Chemical Products and Product Family Trees. In Biorefineries-Industrial Processes and Products. Status Quo and Future Directions; Kamm, B., Gruber, P.R., Kamm, M., Eds.; Wiley-VCH: Weinheim, Germany, 2006; pp. 97-149. 
117. Bozell, J.J.; Hollday, J.E.; Johnson, D.; White, J.F. Top Value Added Chemicals From Biomass. Volume II-Results of Screening for Potential Candidates from Biorefinery Lignin; Pacific Northwest National Laboratory (PNNL) and the National Renewable Energy Laboratory (NREL): Richland, WA, USA, 2007.

118. Chum, H.; Faaij, A.; Moreira, J.; Berndes, G.; Dhamija, P.; Dong, H.; Gabrielle, B.; Goss Eng, A.; Lucht, W.; Mapako, M.; et al. Bioenergy. In IPCC Special Report on Renewable Energy Sources and Climate Change Mitigation; Edenhofer, O., Pichs-Madruga, R., Sokona, Y., Seyboth, K., Matschoss, P., Kadner, S., Zwickel, T., Eickemeier, P., Hansen, G., Schlömer, S., et al., Eds.; Cambridge University Press: Cambridge, UK; New York, NY, USA, 2011.

119. Winkel, G. (Ed.) Towards a Sustainable European Forest-Based Bioeconomy-Assessment and the way forward. What Science Can Tell Us 8; European Forest Institute: Joensuu, Finland, 2017.

120. Ludwig, G.; Köck, W.; Tronicke, C.; Gawel, E. Rechtsrahmen der Bioökonomie in MitteldeutschlandBestandsaufnahme und Bewertung; UFZ Discussion Papers 22/2014; UFZ: Leipzig, Germany, 2014.

121. Ludwig, G.; Köck, W.; Tronicke, C.; Gawel, E. Der Rechtsrahmen für die Bioökonomie in Deutschland. Die Öffentliche Verwaltung (DÖV) 2015, 68, 41-54.

122. O’Rourke, D.; Connolly, S. Just Oil? The Distribution of Environmental and Social Impacts of Oil Production and Consumption. Annu. Rev. Environ. Resour. 2003, 28, 587-617. [CrossRef]

123. Harfoot, M.B.J.; Tittensor, D.P.; Knight, S.; Arnell, A.P.; Blyth, S.; Brooks, S.; Butchart, S.H.M.; Hutton, J.; Jones, M.I.; Kapos, V.; et al. Present and future biodiversity risks from fossil fuel exploitation. Conservat. Lett. 2018, 11, 12448. [CrossRef]

124. German Bioeconomy Council Holz in der Bioökonomie-Chancen und Grenzen. Available online: https://biooekonomierat.de/fileadmin/Publikationen/empfehlungen/BOER_Memo_Holz.pdf (accessed on 29 March 2019).

125. Kröger, M.; Raitio, K. Finnish forest policy in the era of bioeconomy: A pathway to sustainability? For. Policy Econ. 2017, 77, 6-15. [CrossRef]

126. Kleinschmit, D.; Mansourian, S.; Wildburger, C.; Purret, A. (Eds.) Illegal Logging and Related Timber Trade-Dimensions, Drivers, Impacts and Responses. A Global Scientific Rapid Response Assessment Report; IUFRO World Series; IUFRO: Vienna, Austria, 2016; Volume 35.

127. O'Brien, M.; Bringezu, S. What Is a Sustainable Level of Timber Consumption in the EU: Toward Global and EU Benchmarks for Sustainable Forest Use. Sustainability 2017, 9, 812. [CrossRef]

128. Henders, S.; Ostwald, M. Forest Carbon Leakage Quantification Methods and Their Suitability for Assessing Leakage in REDD. Forests 2012, 3, 33-58. [CrossRef]

129. Kallio, A.M.I.; Solberg, B.; Käär, L.; Päivinen, R. Economic impacts of setting reference levels for the forest carbon sinks in the EU on the European forest sector. For. Pol. Econ. 2018, 92, 193-201. [CrossRef]

130. Unruh, G.C. Understanding carbon lock-in. Energy Pol. 2000, 28, 817-830. [CrossRef]

131. Carus, M.; Dammer, L.; Essel, R. Options for Designing the Political Framework of the European Bio-based Economy. Ind. Biotechnol. 2016, 10. [CrossRef]

132. Banerjee, A.; Schelly, C.L.; Halvorsen, K.E. Constructing a Sustainable Bioeconomy: Multi-Scalar Perceptions of Sustainability. In Towards a Sustainable Bioeconomy: Principles, Challenges and Perspectives, 1st ed.; Leal Filho, W., Pociovalisteanu, D.-M., Borges de Brito, P., Borges de Lima, I., Eds.; World Sustainability Series; Springer International Publishing: Cham, Switzerland, 2018. [CrossRef]

133. Gawel, E.; Purkus, A.; Pannicke, N.; Hagemann, N. A Governance Framework for a Sustainable Bioeconomy: Insights from the Case of the German Wood-based Bioeconomy. In Towards a Sustainable Bioeconomy: Principles, Challenges and Perspectives, 1st ed.; Leal Filho, W., Pociovalisteanu, D.-M., Borges de Brito, P., Borges de Lima, I., Eds.; World Sustainability Series; Springer International Publishing: Cham, Switzerland, 2018. [CrossRef]

134. Ahlheim, M. Environmental Economics, the Bioeconomy and the Role of Government. In Bioeconomy. Shaping the Transition to a Sustainable, Biobased Economy, 1st ed.; Lewandowski, I., Ed.; Springer: Cham, Switzerland, 2018. [CrossRef]

135. Jenkins, J.D. Political Economy Constraints on Carbon Pricing Policies: What are the Implications for Economic Efficiency, Environmental Efficacy, and Climate Policy Design? Energy Pol. 2014, 69, 467-477. [CrossRef] 
136. Lahl, U. Bioökonomie für den Klima -und Ressourcenschutz - Regulative Handlungskorridore. Available online: https://www.nabu.de/imperia/md/content/nabude/gentechnik/studien/140821-nabu-biooekonomiestudie_2014.pdf (accessed on 29 March 2019).

137. Adler, P.; Budzinski, M.; Erdmann, G.; Majer, S.; Meisel, K.; Schock, S.; Thrän, D. Sachstandsbericht über vorhandene Grundlagen für ein Monitoring der Bioökonomie: Nachhaltigkeit und Ressourcenbasis der Bioökonomie; Deutsches Biomasseforschungszentrum (DBFZ): Leipzig, Germany, 2015.

138. Fischer, C.; Newell, R.G. Environmental and Technology Policies for Climate Mitigation. J. Environ. Econ. Manag. 2008, 55, 142-162. [CrossRef]

139. Jaffe, A.B.; Newell, R.G.; Stavins, R.N. A Tale of Two Market Failures: Technology and Environmental Policy. Ecol. Econ. 2005, 54, 164-174. [CrossRef]

140. Arrow, K.J. Economic Welfare and the Allocation of Resources for Invention. In The Rate and Direction of Invention Activity; Nelson, R., Ed.; Princeton University Press: Princeton, PA, USA, 1975.

141. Arthur, B.W. Competing Technologies, Increasing Returns, and Lock-In by Historical Events. Econ. J. 1989, 99, 116-131. [CrossRef]

142. Eckpunktepapier des Bioökonomierates: "Auf dem Weg zur Biobasierten Wirtschaft“ (Politische und Wissenschaftliche Schwerpunkte 2013-2016). Available online: https:/biooekonomierat.de/fileadmin/ Publikationen/empfehlungen/BOER_Eckpunktepapier_2013.pdf (accessed on 22 May 2019).

143. Wyman, C.; Goodman, B. Biotechnology for production of fuels, chemicals, and materials from biomass. Appl. Biochem. Biotechnol. 1993, 39-40, 41-59. [CrossRef]

144. Hagemann, N.; Gawel, E.; Purkus, A.; Pannicke, N.; Hauck, J. Possible futures towards a wood-based bioeconomy: A scenario analysis for Germany. Sustainability 2016, 8, 98. [CrossRef]

145. Purkus, A.; Hagemann, N.; Bedtke, N.; Gawel, E. Towards a sustainable innovation system for the German wood-based bioeconomy: Implications for policy design. J. Clean. Prod. 2018, 172, 3955-3968. [CrossRef]

146. Grubler, A.; Aguayo, F.; Gallagher, K.S.; Hekkert, M.; Jiang, K.; Mytelka, L. Policies for the Energy Technology Innovation System; Global Energy Assessment: Cambridge, UK, 2012.

147. Foxon, T.J.; Gross, R.; Chase, A.; Howes, J.; Arnall, A.; Anderson, D. UK innovation systems for new and renewable energy technologies: drivers, barriers and systems failures. Energy Pol. 2005, 33, 2123-2137. [CrossRef]

148. Van Stappen, F.; Brose, I.; Schenkel, Y. Direct and indirect land use changes issues in European sustainability initiatives: State-of-the-art, open issues and future developments. Biomass Bioenergy 2011, 35, 4824-4834. [CrossRef]

149. Frank, S.; Böttcher, H.; Havlík, P.; Valin, H.; Mosnier, A.; Obersteiner, M.; Schmid, E.; Elbersen, B. How effective are the sustainability criteria accompanying the European Union 2020 biofuel targets? GCB Bioenergy 2013, 5, 306-314. [CrossRef]

150. Wolfslehner, B.; Linser, S.; Pülzl, H.; Bastrup-Birk, A.; Camia, A.; Marchetti, M. Forest Bioeconomy-A New Scope for Sustainability Indicators. From Science to Policy 4; European Forest Institute: Joensuu, Finland, 2016.

151. Stern, T.; Ploll, U.; Spies, R.; Schwarzbauer, P.; Hesser, F.; Ranacher, L. Understanding Perceptions of the Bioeconomy in Austria-An Explorative Case Study. Sustainability 2018, 10, 4142. [CrossRef]

152. Philippidis, G.; Sanjuán-López, A.I. A Re-Examination of the Structural Diversity of Biobased Activities and Regions across the EU. Sustainability 2018, 10, 4325. [CrossRef]

153. Davies, S.; Griestop, L.; Vironen, H.; Bachtler, J.; Dozhdeva, V.; Michie, R. Case Studies of National Bioeconomy Strategies in Finland and Germany. Available online: Cordis.europa.eu/result/rcn/198231_en.html (accessed on 17 August 2018).

154. Mustalahti, I. The responsive bioeconomy: The need for inclusion of citizens and environmental capability in the forest based bioeconomy. J. Clean. Prod. 2018, 172, 3781-3790. [CrossRef]

155. Toppinen, A.; Autio, M.; Sauru, M.; Berghäll, S. Sustainability-Driven New Business Models in Wood Construction Towards 2030. In Towards a Sustainable Bioeconomy: Principles, Challenges and Perspectives, 1st ed.; Leal Filho, W., Pociovalisteanu, D.-M., Borges de Brito, P., Borges de Lima, I., Eds.; World Sustainability Series; Springer International Publishing: Cham, Switzerland, 2018. [CrossRef]

156. Egea, F.J.; Torrente, R.G.; Aquliar, A. An efficient agro-industrial complex in Almeria (Spain): Towards an integrated and sustainable bioeconomy model. New Biotechnol. 2018, 40, 103-112. [CrossRef] 
157. Hildebrandt, J.; O'Keeffe, S.; Bezama, A.; Thrän, D. Revealing the Environmental Advantages of Industrial Symbiosis in Wood-Based Bioeconomy Networks: An Assessment From a Life Cycle Perspective. J. Ind. Ecol. 2018. [CrossRef]

158. O'Neill, D.; Fanning, A.L.; Lamb, W.F.; Steinberger, J.K. A good life for all within planetary boundaries. Nat. Sustain. 2018, 1, 88-95. [CrossRef]

159. Hahn, R. Sustainable Development and Sustainability Management. In Bioeconomy. Shaping the Transition to a Sustainable, Biobased Economy, 1st ed.; Lewandowski, I., Ed.; Springer: Cham, Swtizerland, 2018. [CrossRef]

160. Sijtsema, S.; Onwezen, M.; Reinders, M.; Dagevos, H.; Meeusen, M. Acceptance Factors for Bio-Based Products and Related Information Systems among Consumers; Opening Bio-Based Markets via Standards, Labelling and Procurement -Open-BIO: Wageningen, Germany, 2015.

161. Rudolph, K. Barriers to Acceptance of Bio-Based Substitutes: How Schema Incongruity Can Hinder the Purchase of Bio-Based Products. In Towards a Sustainable Bioeconomy: Principles, Challenges and Perspectives, 1st ed.; Leal Filho, W., Pociovalisteanu, D.-M., Borges de Brito, P., Borges de Lima, I., Eds.; World Sustainability Series; Springer International Publishing: Cham, Switzerland, 2018. [CrossRef]

(C) 2019 by the authors. Licensee MDPI, Basel, Switzerland. This article is an open access article distributed under the terms and conditions of the Creative Commons Attribution (CC BY) license (http://creativecommons.org/licenses/by/4.0/). 